\title{
Teacher Training and Student Assessment: At Odds?
}

Michael Bardzell and Jennifer Bergner

Slipping standards for mathematics education in the United States have been a concern both at the state and national levels for many years. The role of the federal government and funding strategies to support education play a significant role in discussions on how to best address deficiencies in the American education system. There remain many diverse opinions on how to best improve student learning in mathematics. In [1] an argument is made that improving teacher quality is the key to better student learning and performance in mathematics and that this will necessitate further efforts in training and teacher support. How should taxpayer money be spent to improve teacher quality? There is a plethora of teacher professional development programs that focus on involving teachers in authentic mathematical experiences appropriate for their own classrooms. These programs share instructional materials and innovative approaches to classroom mathematics and engage teachers in standards-based mathematics instruction. Many such programs

Michael Bardzell is professor of mathematics at Salisbury University. His email address is mjbardze11@sa 1 i sbury. edu.

Jennifer Bergner is professor of mathematics at Salisbury University. Her email address is jabergner@sa1 i sbury. edu.

Members of the Editorial Board for Doceamus are: David Bressoud, Roger Howe, Karen King, William McCallum, and Mark Saul.

DOI: http://dx.doi.org/10.1090/noti1002 are funded by federal and state governments that put huge emphasis on standardized tests which assess how students implement basic mathematical algorithms instead of deeper conceptual understanding and more involved problem-solving skills. These professional development programs show how to make connections in mathematical knowledge by taking time to investigate, question, and conjecture. However, state tests point teachers in quite a different direction.

In recent years testing has been driven by No Child Left Behind (NCLB), although each state has its own set of standards. These high-stakes state tests focus on a small subset of mathematical skills which students should master. The questions are multiple choice or require short expository responses that do not reveal if a student has deep conceptual understanding of a topic. As student performance is used to measure how "successful" a school is, this encourages teaching of these concepts to be done in a linear and formulaic manner which does not emphasize connections between ideas. It also encourages teachers to turn the month before the state test into multiple cram sessions on how to do procedure $X$ when key word/ phrase $Y$ is used in test questions. Ironically, much of the recently funded professional development has emphasized the importance of taking time to focus on mathematical content knowledge, problem solving, critical thinking skills, and a more integrated approach to mathematical learning with connections to other disciplines. But these 
programs have also deemphasized many rote procedures in K-12 mathematics.

We often hear from teachers that they would love to take the activities and approaches they see during their professional development programs into their classroom, but they are afraid to because the approach does not focus students on tested procedures and would distract them from the test items. We tell these educators that if their students can do more innovative and involved mathematics activities, then the rote type problems on standardized tests should be easier for them. But this is a tough sell to teachers who are under the gun with high-stakes tests that place so much importance on procedures. Teachers are told to implement inquiry-based learning approaches during their professional development, but the state tests send the message to teach isolated procedures.

Now the Common Core State Standards (CCSS) will define much of the $\mathrm{K}-12$ educational climate for the foreseeable future (see [2] for one perspective). Although these standards were not written by the federal government, forty-five states have agreed to use the CCSS, making it a more nationalized effort than NCLB. CCSS describes eight standards for mathematical practice (see www. corestandards.org) and standards for mathematics content that are a "balanced combination of procedure and understanding." If test developers (like Smarter Balance and Partnership for Assessment of Readiness for College and Careers) write tests in alignment with the intent of CCSS, then the emphasis on rote memorization and isolated skills will be forced to change. Many school systems are already engaged in training for their teachers that involve the eight standards for mathematical practice. They are also in the process of redesigning curriculum guides to address the content standards. It is not yet clear what types of test questions will be written and how they will be evaluated. Will these new high-stakes tests measure a balance of procedure and understanding to test whether students can engage in a meaningful way with mathematics? Or will states once again push teachers towards isolated procedures and repeat the mistakes of NCLB? That remains to be seen.

So the question remains: what should professional development for $\mathrm{K}-12$ teachers be in this current educational and fiscal climate? If test developers can find ways to create tests that better evaluate conceptual mathematical understanding, then CCSS-based professional development could be a step in the right direction. Teachers would engage in authentic mathematical experiences, share successful pedagogical approaches, and ultimately use these more innovative and creative techniques in the classroom. However, if test developers continue to write tests that focus too much on the successful completion of procedures, then such professional development programs will leave teachers facing their current pedagogical paradox. As Dr. William Schmidt claims, "What is clear in the research is that the Common Core State Standards for Mathematics are an important improvement over the state standards that they replaced and that, to see their full potential realized, they must be implemented well." He bases this claim on his research ([3]) which found that "States with past mathematics standards that were more similar to the CCSSM had statistically significantly higher NAEP (National Assessment of Educational Progress) 2009 performance."

In recent years, the "assessment" and "spending" arms of the federal and state governments have quite literally been working against each other. This has serious implications for our K-12 classrooms and the future of mathematics education. The debt ceiling crisis in Washington last year and the lead-up to the 2012 presidential election give us an indication of the tone and contention fiscal debates will have over the next several years. Our country has some tough decisions to make over our finances. But we also have many challenges regarding the current trajectory of the American K-12 education system, particularly with mathematics. Can we afford strong ongoing support of STEM education (mathematics in particular) and, in turn, meaningful teacher professional development? Can we afford not to support them? Either way, in-service teacher preparation will be important over the next decade. Whatever the future level of funding is for supporting initiatives, it is imperative that our teacher professional development and subsequent assessment efforts not be at odds. Sending teachers conflicting messages about how to run their classrooms is not only a misuse of taxpayer dollars, but it is harmful for the education of our students. While the levels of education funding will receive much of the spotlight over the next several years, we hope that the mathematical and education communities can work together and ensure that, whatever the funding, it is used in the most productive way to support our K-12 teachers and, ultimately, their students. The Common Core may provide an opportunity to take a step in the right direction if it can move us away from NCLB type assessments. In the future, we look forward to implementing meaningful teacher professional development that is consistent with both CCSS and student assessment.

\section{References}

[1] IRwIN KRA, (Math) Teachers are the key, Notices of the AMS, Volume 59, Number 4, April 2012, 556-557.

[2] SOLOMON GARFUNKEL, The Common Core State Standards-Education reform and us, Notices of the AMS, Volume 58, Number 6, June/July 2011, 820-821.

[3] Achieve, 2012, Common Core Math Standards implementation can lead to improved student achievement [Press conference]. Retrieved from http://www. achieve.org/CCSS-schmidt-research, video at http://vimeo.com/41542448. 